\title{
NFIB wt Allele
}

National Cancer Institute

\section{Source}

National Cancer Institute. NFIB wt Allele. NCI Thesaurus. Code C53093.

Human NFIB wild-type allele is located in the vicinity of 9p24.1 and is approximately 233 $\mathrm{kb}$ in length. This allele, which encodes nuclear factor $1 \mathrm{~B}$-type protein, is involved in both the modulation of transcription by RNA polymerase II and the activation of DNA replication. 